Çukurova Üniversitesi Mühendislik Mimarlık Fakültesi Dergisi, 33(1), ss. 117-130, Mart 2018

Çukurova University Journal of the Faculty of Engineering and Architecture, 33(1), pp. 117-130, March 2018

\title{
Erken Yaş Yüksek Dayanımlı Çimento Bağlayıcılı Kompozitlerle Üretilen Onarım Sistemlerinin Eğilme Performansı ve Yansıma Çatlağı Davranışı
}

\begin{abstract}
Gürkan YILDIRIM ${ }^{* 1}$

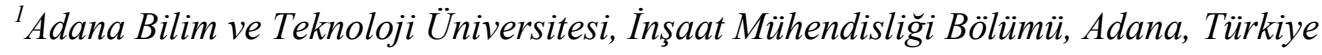

Geliş tarihi: 10.01 .2018

Kabul tarihi: 14.03.2018

$\ddot{\mathbf{O} z}$

Çalışma kapsamında, yüksek süneklilik ve çekme yüklemeleri altında sergilenen çoklu dar çatlak genişlikleri özelliklerinden ödün vermeden erken yaş yüksek dayanımlı ve onarılacak beton ile en yüksek derecede bağ kuracak yeni nesil onarım malzemeleri tasarlanmış ve bu malzemelerin performansı piyasada yaygın olarak kullanılan bir başka onarım malzemesiyle karşılaştırılmıştır. Çalışmanın birinci bölümünde monolitik halde test edilen karışımların temel mekanik özellikleri değerlendirilmiştir. İkinci bölümde ise tabakalı olarak hazırlanan karışımların onarım malzemesi olarak kullanılabilirlikleri eğilme performansı ve yansıma çatlağı davranışları göz önünde bulundurularak değerlendirilmiştir. Çalışma kapsamında üretilen HESECC karışımlarının tamamı literatürde bir onarım malzemesinden erken yaşta beklenen temel mekanik özelliklerin tamamını fazlasıyla karşılamış ve üretilen tabakalı numuneler, piyasada yaygın bir şekilde kullanılan OM numunelerine kıyasla çok daha sünek bir davranış sergileyerek yansıma çatlağının yayılımını önemli ölçüde azaltmıştır.
\end{abstract}

Anahtar Kelimeler: Tasarlanmış çimento bağlayıcılı kompozitler, Onarım, Bağ özellikleri

\section{Flexural Performance and Reflective Cracking Behavior of Repair Systems Produced with High Early Strength Cementitious Composites}

\begin{abstract}
In this study, new generation high early strength repair materials compatible with the existing concrete substrate were produced without compromising increased ductility and multiple micro-cracking behavior and the performance of these repairs was compared with a commercially available high early strength repair material. In the first section of the study, basic mechanical properties of monolitically tested mixtures were assessed. In the second section, usability of mixtures produced in the layered state as a repair material was investigated by focusing on flexural performance and reflective cracking behavior. HESECC mixtures produced herein adequately satisfied the early age mechanical properties expected from a certain repair material and layered specimens which significantly minimized the propagation of reflective cracking exhibited relatively higher ductility compared to REP material widely used and available in the related markets.
\end{abstract}

Keywords: Engineered cementitious composites, Repair, Bond properties

*Sorumlu yazar (Corresponding author): Gürkan YILDIRIM, gyildirim@adanabtu.edu.tr 


\section{GİRIŞ}

Dünya çapında, özellikle ülkemizde, mevcut durumda var olan birçok beton yapının bozulma durumunda olduğu çok iyi bilinen bir gerçektir [1]. Atmosferde artan $\mathrm{CO}_{2}$ konsantrasyonunun beton yapıların kimyasal kararlılığını zamanla daha da zayıflatması beklenmektedir [2]. Beton yapıların bakım ve onarımı, mekanik yüklerin ve çevresel faktörlerin ortak etkisi altında doğal olarak bozulan malzemeler ve altyap1 sebebiyle, sürekli tekrarlanan bir ihtiyaç durumuna gelmiştir. Geçmişte, bozulmuş eski ve hasarlı yapılar yenileriyle değiştirilmekteydi. Ancak, bugünün belirsiz ekonomik koşulları ve değişim için gerekli yüksek maliyet sebebiyle, bozulan yapıların değiştirilmesinden ziyade onarılması veya güçlendirilmesi üzerinde daha çok durulmaktadır. Hem Türkiye hem de Avrupa'da inşaat işlerinin büyük bir bölümü var olan yapıların onarım, güçlendirme ve iyileştirmesini kapsamaktadır.

Onarım endüstrisinde gösterilen çabalara rağmen, beton onarım malzemelerinin ihtiyaçları karşılayamadığı durumlar oldukça yaygındır. Beton onarımında kullanılan malzemelerin neredeyse yarısının saha şartlarında başarısız olduğu tahmin edilmektedir [3]. Mevcut durumda kullanılmakta olan onarım malzemelerinin genellikle erken yaş düşük performanslarından ve/veya uzun vadede düşük dayanıklılık özelliklerinden kaynaklanan ciddi problemleri bulunmaktadır. Bu sebeple, erken ve nihai yaşta yüksek performans özelliğine sahip ve mevcut yapıyı uzun vadede mekanik ve çevresel yüklere karşı koruyabilecek etkili çok yüksek performanslı onarım malzemelerinin geliştirilmesi beton yapıların onarımında hayati bir öneme sahiptir.

Son yıllarda yapılmış olan çalışmalarda Tasarlanmış Lif Donatılı Çimento Bağlayıcılı Kompozitlerin (patent ismi Engineered Cementitious Composites [ECC]) onarım ve güçlendirme işlerinde başarılı bir şekilde kullanılabileceği gözlemlenmiştir. Şekil değiştirme sertleşmesi gösteren yüksek performanslı lif donatılı çimento bağlayıcılı kompozitler (bundan sonra ECC olarak kısaca ifade edilecek), yüksek süneklilik ve dayanıklılık için mikro-mekanik tabanlı tasarım yaklaşımları kullanılarak tasarlanan oldukça yeni ve gelecek vadeden bir kompozit malzeme sinıfidır [4,5]. Geleneksel ve lif donatılı beton türlerinden farklı olarak, bu kompozit malzeme ilk çatlaktan sonra sünek bir malzeme gibi şekil değiştirme sertleşmesi göstermekte olup normal ve lif donatılı betonların yaklaşık 300 ile 500 katı kadar daha fazla çekme şekil değiştirme kapasitesine sahiptir. Ayrica, ECC, normal ve lif donatılı betonlardan farklı olarak, yük altında kendi kendine çatlak kontrolü sağlayan bir davranış sergilemektedir. Numunedeki nihai deformasyon ne olursa olsun, ortalama çatlak genişliği yaklaşık $200 \mu \mathrm{m}$ veya daha düşük seviyelerde kalmaktadır. ECC'nin çekme yükleri altında göstermiş olduğu yüksek sünekliliği ve çoklu mikro çatlak davranışı, bu kompozitin beton yapıların onarımında kullanılması durumunda onarılmış yapıların dürabilitesi için çok önemli iki özellik olduğu daha önceleri yapılan çalışmalarda ispatlanmıştır.

ECC'nin mikromekanik tabanlı tasarım yaklaşımı uyarınca, çoklu mikro çatlak hasarı oluşumunun (şekil değiştirme sertleşmesi özelliğiyle birlikte gelen yüksek süneklik) önünde engel oluşturan yüksek matris kırılma tokluğu değerlerinin daha düşük seviyelere çekilmesi ve liflerin matris içerisinde daha homojen bir şekilde dağıtılabilmeleri amacıyla karışımlarda iri agrega kullanılmamakta ve bu durum daha yüksek oranlarda Portland çimentosu kullanımını tetiklemektedir. Portland çimentosunun k1smi olarak puzolanik malzemelerle ikame edilmesinin, bu malzemelerin üretiminin çimentodan daha $\mathrm{az}$ enerji gerektirmesi ve $\mathrm{CO}_{2}$ emisyonunu azaltmaları gibi sebeplerden ötürü toplam malzeme maliyetini ve çevresel etkileri azaltıp, doğallığı artırmaları beklenebilir. Farklı puzolanik malzemeler arasından uçucu kül ve ögütülmüş granüle yüksek firın cürufu mevcut durumda en yaygın bulunabilecek puzolanik malzemelerdendir. Bu endüstriyel yan ürünler fazla miktarlarda mevcut olup, genel olarak çimentoya kıyasla daha ucuz ve doğaldırlar. Önceki çalışmalar ECC karışımlarında Portland çimentosunun değişik oranlarda farklı puzolanik malzemelerle yer değiştirilebileceğini 
göstermiştir [4-10]. Bu olumlu katkılarına ilaveten yüksek hacimlerde endüstriyel atıkların kullanımı ECC karışımının erken yaş dayanımını olumsuz bir biçimde etkilemektedir. Ancak özellikle hızlı onarım ve tadilat işlerinde kullanılacak malzemelerin erken yaş dayanımlarının genellikle çok yüksek olması ve böylece çevreye verilen rahatsızlığın en düşük düzeye düşürülmesi beklenmektedir. Örneğin havaalanı pistlerinin veya köprü döşemelerinin onarımında kullanılacak malzemelerinin erken yaş çok yüksek dayanıma sahip olması ve böylelikle tamir edilen pistin veya köprünün 6-8 saat sonrasında veya bazen daha erken sürelerde kullanıma tekrar açılması beklenmektedir.

$\mathrm{Bu}$ çalışmada yüksek süneklilik ve çekme yüklemeleri altında meydana gelecek çoklu dar çatlak genişlikleri özelliklerinden ödün vermeden erken yaş yüksek dayanımlı (high-early-strength [HES]) yeni nesil ECC karışımları (HESECC) geliştirilmiştir. Deneysel program kapsamında öncelikle monolitik HESECC karışımlarının temel mekanik özellikleri (basınç dayanımı, eğilme dayanımı ve sehim) değerlendirilmiştir. Daha sonra, HESECC karışımları alt tabaka betonuyla beraber tabakalı şekilde üretilmiş ve muhtemel bir onarım malzemesi olarak kullanılabilirliği eğilme performansı ve yansıma çatlağı davranışı bakımından değerlendirilmiştir. Çalışmanın her aşamasında monolitik ve tabakalı HESECC numunelerinin performansı mevcut durumda inşaat sektöründe yaygın bir biçimde kullanılmakta olan ve BASF Yap1 Kimyasalları'ndan temin edilen erken yaş yüksek dayanımlı bir onarım malzemesi ile karşılaş̧ırılmıştır.

\section{MATERYAL VE METOT}

\subsection{Malzemeler}

HESECC karışımların üretimi sırasında CEM I 52,5R tipi erken yaş yüksek dayanıma sahip Süper Beyaz Portland Çimentosu (PÇ) temel bağlayıcı malzeme olarak kullanılmıştır. Çimsa Çimento Mersin fabrikasından temin edilen çimentonun kimyasal kompozisyonu ve fiziksel özellikleri Çizelge 1'de gösterilmektedir. HESECC karışımlarında ayrıca İskenderun Demir Çelik Fabrikası'nın endüstriyel atığı olan ve OYSA İskenderun Çimento Fabrikası'nda belirli bir incelik değerine kadar öğütülmüş yüksek firın cürufu (C) kullanılmıştır. Cürufun kimyasal özellikleri kompozisyonu ve fiziksel özellikleri Çizelge 1'de gösterilmektedir. Lif dağılımının kolaylığı ve matris kırılma tokluğu değerlerinin düşük seviyelerde tutulabilmesi amaciyla HESECC karışımlarında en büyük tane boyutu $400 \mu \mathrm{m}$ olan mikro-kuvars kumu kullanılmıştır. Kuvars kumunun çeşitli özellikleri Çizelge 1'de gösterilmektedir.

Çizelge 1. HESECC üretiminde kullanılan çimento, cüruf ve kumun özellikleri

\begin{tabular}{|l|c|c|c|c|c|c|c|c|c|c|}
\hline \multirow{2}{*}{ Malzeme } & \multicolumn{7}{|c|}{ Kimyasal Kompozisyon (\%) } & \multicolumn{3}{c|}{ Fiziksel Özellikler } \\
\cline { 2 - 12 } & $\mathrm{CaO}$ & $\mathrm{SiO}_{2}$ & $\mathrm{Al}_{2} \mathrm{O}_{3}$ & $\mathrm{Fe}_{2} \mathrm{O}_{3}$ & $\mathrm{MgO}$ & $\mathrm{K}_{2} \mathrm{O}$ & $\mathrm{Na}_{2} \mathrm{O}$ & $\begin{array}{c}\text { K1zdırma } \\
\text { Kayb1 }\end{array}$ & $\begin{array}{c}\text { Özgül } \\
\text { ağırlık }\end{array}$ & $\begin{array}{c}\text { Blaine } \\
\text { inceliği } \\
\left(\mathrm{cm}^{2} / \mathrm{g}\right)\end{array}$ \\
\hline $\mathrm{PÇ}$ & 65,7 & 21,6 & 4,10 & 0,26 & 1,30 & 0,77 & 0,19 & 3,20 & 3,06 & 4600 \\
\hline $\mathrm{C}$ & 35,1 & 37,6 & 10,6 & 0,28 & 7,90 & 1,10 & 0,24 & 2.80 & 2,79 & 4250 \\
\hline Kum & 0,02 & 99,79 & 0,06 & 0,02 & 0,01 & 0,01 & 0,02 & 0,07 & - & - \\
\hline
\end{tabular}

Matris kırılma tokluğu seviyelerinin daha düşük seviyelere çekilebilmesi ve özellikle tabakalı numunelerin bağ özelliklerini olumsuz etkilemesi muhtemel erken yaş rötre oluşumunun azaltılması amacıyla bazı HESECC karışımlarının üretiminde tane büyüklükleri 1-2 $\mathrm{mm}$ arasında değişen suya doygun hafif perlit agregası (HA)'da toplam agrega hacminin \%50'si oranında kullanılmıştır (HESECC-HA). HA'nın yaklaşık su emme kapasitesi ağırlıkça \%131, özgül ağırlığı ise 0,92'dir. HESECC karışımlarının işlenebilirliğini arttırmak için akrilik esaslı polikarboksilik eter tipi 
Erken Yaş Yüksek Dayanımlı Çimento Bă̆layıcılı Kompozitlerle Üretilen Onarım Sistemlerinin Eğilme Performansı ve Yansıma Çatlağı Davranışı

bir yüksek oranda su azaltıcı katkı (YOSA) kullanılmıştır. Süper akışkanlaştırıcı katkı miktarı karışım sırasında katkının performansına, elde edilecek karışımların kıvamına, ayrışmaya karşı direncine ve liflerin matrise homojen olarak dağılmasına bağlı olarak ayarlanmıştır. Ayrıca üretilen ECC karışımlarında YOSA katkı ile beraber erken dayanımı arttırmak için özgül ağırlığ 1,3 olan kalsiyum nitrat tuzu esaslı bir priz hızlandırıcı $(\mathrm{PH})$ kimyasal katkı kullanılmıştır. Kompozit malzemelerin üretilmesinde özellikleri Çizelge 2'de gösterilen polivinil-alkol (PVA) lifleri kullanılmıştır. Karşılaştırma amacıyla piyasada kolaylıkla bulunabilen ve yaygın olarak kullanılan bir adet onarım malzemesi de (OM) ayrıca üretilmiştir. Onarım malzemesi olarak, sınırlı zaman diliminde çok yüksek erken dayanımın gerekli olduğu durumlarda rahatlıkla kullanılabilecek bir ürün seçilmiştir. Seçilen onarım malzemesi tek bileşenli olup yapısında polipropilen lif ve polimer katk1lar bulundurmaktadır. Malzeme, üreticinin önerdiği karışım oranlarında su kullanılarak karıştırılarak kolaylıkla dökülebilmektedir.

Çizelge 2. HESECC üretiminde kullanılan PVA lifinin mekanik ve geometrik özellikleri

\begin{tabular}{|c|c|c|c|c|c|c|}
\hline $\begin{array}{c}\text { Nominal } \\
\text { Dayanım (MPa) }\end{array}$ & $\begin{array}{c}\text { Görünen } \\
\text { Dayanım (MPa) }\end{array}$ & $\begin{array}{c}\text { Çap } \\
(\boldsymbol{\mu m})\end{array}$ & $\begin{array}{c}\text { Boy } \\
(\mathbf{m m})\end{array}$ & $\begin{array}{c}\text { Elastisite } \\
\text { Modülü (GPa) }\end{array}$ & $\begin{array}{c}\text { Kopma Uzama } \\
\text { Oranı (\%) }\end{array}$ & $\begin{array}{c}\text { Özgül } \\
\text { Ağırlık }\end{array}$ \\
\hline 1620 & 1092 & 39 & 8 & 42,8 & 6,0 & 1,30 \\
\hline
\end{tabular}

Üretilen karışımların bağ özelliklerinin ve eğilme performanslarının değerlendirilebilmesi için rijit kaplamaların üretiminde yaygın olarak kullanılan alt tabaka betonu (ATB) üretilmiştir. ATB karışımı olarak, en düşük basınç dayanımı $30 \mathrm{MPa}$, eğilme dayanımı ise 4,5 $\mathrm{MPa}$ [11] olan geleneksel beton kullanılmıştır. ATB ince (tane boyutu 0,1 ile 5,0 $\mathrm{mm}$ arasında değişen doğal nehir kumu) ve kaba agregaları (en büyük tane boyutu $12 \mathrm{~mm}$ olan kırma taş) bir arada bulundurmaktadır. ATB'de HESECC karışımlarından farklı olarak CEM I 42,5R Portland çimentosu kullanılmıştır. Ayrıca ATB karışımlarında, donma çözülme direnci için hava sürükleyici katkı (HSK) ile beraber yeterli kıvamın sağlanabilmesi için YOSA katkı kullanılmıştır.

Çizelge 3. HESECC ve ATB karışım oranları

\begin{tabular}{|l|c|c|c|}
\hline Malzemeler, $\mathbf{( k g / \mathbf { m } ^ { 3 } )}$ & HESECC & HESECC-HA & ATB \\
\hline Toplam su & 298 & 298 & -180 \\
\hline CEM I 52,5R & 719 & 719 & 400 \\
\hline CEM I 42,5R & - & - & - \\
\hline Cüruf & 600 & 600 & 920 \\
\hline Kaba agrega & - & - & 900 \\
\hline İnce agrega & - & - & - \\
\hline Kuvars kumu & 587 & 293 & - \\
\hline HA (Perlit) & - & 100 & - \\
\hline PVA lifi & 26,0 & 26,0 & 1,8 \\
\hline YOSA katk1 & 13,8 & 8,2 & - \\
\hline PH katk1 & 12,3 & 12,3 & 0,43 \\
\hline HSK & - & - & 0,45 \\
\hline Toplam [S/(PÇ+C)] & 0,23 & 0,23 & - \\
\hline İK [S/(PÇ+C)]* & - & 0,15 & - \\
\hline Etkin [S/(PÇ+C)] & 0,23 & 0,38 & - \\
\hline HA/toplam kum & - & 0,50 & - \\
\hline C/PÇ & 0,84 & 0,84 & \\
\hline
\end{tabular}

*: Içsel kürleme (IK) suyunun bağlayıcı malzemeye (BM = Çimento+Cüruf) oranı 


\subsection{Karışım Oranları}

Erken yaş yüksek dayanım, çekme sünekliliği ve düşük erken yaş rötre özelliklerinin tümünün bir onarım malzemesinde aynı anda bulunması farklı özelliklerin birbirine uymayan tasarım yaklaşımları sebebiyle elde edilmesi zor bir durumdur. Şu ana kadar, bu tarz onarım malzemelerinin performansıyla ilgili literatürde bulunan bilgiler oldukça kısıtlıdır. Yazar tarafından daha önceden gerçekleştirilen çalışmalarda arzu edilen HESECC malzeme özelliklerinden (ör. yüksek çekme sünekliliği) taviz verilmeksizin belirlenen en düşük basınç dayanımının (6 saatte $20 \mathrm{MPa}$ civarı) elde edilebilmesi için mikro-mekanik tasarım kısıtlamaları göz önünde bulundurularak çeşitli deneme karışımları üretilmiştir.

Bu bağlamda iki farklı su-bağlayıcı malzeme oranı (S/BM, 0,23 ve 0,34) ve üç farklı cüruf-Portland çimentosu oranına (C/PÇ, $0,00,0,60$ ve 0,84$)$ sahip çeşitli karışımlar geliştirilmiştir [12]. Ön deneyler sonrasında daha önce bahsedilen özelliklerin eş zamanlı barındirılması bakımından optimum performansı sergileyen ve oranları Çizelge 3'te gösterilen HESECC karışımları OM karışımı ile birlikte monolitik ve tabakalı şekilde tekrar üretilmiştir. Tekrar üretilen karışımların temel mekanik özellikleri ve onarım malzemesi olarak kullanılabilirlikleri eğilme performansı ve yansıma çatlağı davranışı bakımından değerlendirilmiştir.

\subsection{Numunelerin Üretilmesi ve Test Edilmesi}

Temel mekanik özellikler başlığı altında karışımların basınç dayanımı, eğilme dayanımı ve sehim sonuçları değerlendirilmiştir. Her bir karışımdan basınç dayanımı testinde kullanılmak üzere küp $(50 \times 50 \times 50 \mathrm{~mm})$ numuneler üretilmiştir. 6 saat, 7 gün ve 28 günlük yaşlarda her yaş için 6 numune olmak üzere her bir karışım için toplam 18 numune test edilmiştir. Basınç dayanımı testi ASTM C39 standardina uygun olarak 100 ton kapasiteli bir test cihazı kullanılarak gerçekleştirilmiştir.

Eğilme altında özelliklerin belirlenebilmesi amacıyla $360 \times 75 \times 50 \mathrm{~mm}$ boyutlarında kiriş numuneler üretilmiştir. 6 saat, 7 gün ve 28 günlük yaşlarda her yaș için 6 numune olmak üzere her bir karışım için toplam 18 numune test edilmiştir. Eğilmede çekme deneyi deformasyon kontrollü test cihazında yapılmış olup karışımların eğilme yükü altında özelliklerinin belirlenmesi için kiriş numuneleri üzerinde, önce numune temizlenerek yüklerin uygulanacağı noktalar belirlenmiş ve dört noktalı eğilmede çekme yüklemesi uygulanmıştır. Deneyler sırasında kiriş numuneler 304 mm'lik açıklık üzerine oturtulmuş ve eğilme yüklemesi 101 mm'lik açıklık esas alınarak uygulanmıştır. Eğilme deneyleri, kapalı devre elektro-mekanik test cihazı ile deformasyon kontrollü olarak (literatürde yapılmış olan çalışmalarda olduğu gibi $0,005 \mathrm{~mm} /$ saniye hızla) yapılmıştır. Deney sırasında, numunenin orta noktasında oluşan sehim (saniyede 10 veri olacak şekilde) ve buna karşılık gelen yük bilgisayar sistemi sayesinde hassas bir şekilde kaydedilmiştir. Ayrıca yükleme sırasında numunelerin orta noktasinda meydana gelen sehim, elektro-mekanik test cihazının yapmakta olduğu sehim ölçümlerine paralel olarak, numunenin orta noktasına LVDT sabitlenerek de ölçülmüştür. Nihai sehim değerleri cihaz ve LVDT'den kaydedilen sonuçların ortalaması alınarak hesaplanmıştır.

Farklı testlerde kullanılan küp ve kiriş numuneler hep birlikte ortalama sicaklığ $23 \pm 2{ }^{\circ} \mathrm{C}$ ve nemi $\% 95 \pm 5$ olan özel hava geçirimsiz poşetlerde deney tarihine kadar muhafaza edilmiştir. $\mathrm{Bu}$ kür yönteminin seçilmesinin ana sebebi literatürde ECC için kullanılan en yaygın kür yönteminin bu şekilde olmasıdır, ayrıca bu şekilde uygulanan kürün gerçek saha şartlarına daha uygun olduğu düşünülmektedir. Böylelikle elde edilen deneysel sonuçlar kolaylıkla literatürde yayınlanmış çalışmalarla da karşılaştırılabileceklerdir.

Onarım malzemesi olarak seçilen HESECC ve OM karışımlarının alt tabaka betonu (ATB) üzerine uygulanarak, tabakalı halde eğilme dayanımlarını tayin etmek amacıyla dört noktalı eğilmede çekme deneyi yapılmıştır. $\mathrm{Bu}$ deney için öncelikle $400 \times 75 \times 80 \mathrm{~mm}$ boyutlarındaki demir kiriş kalıplara ATB dökülerek 24 saat sonra numuneler kalıptan çıkartılıp 27 gün boyunca kirece doygun suda bekletilmişlerdir. $\mathrm{Bu}$ sürenin sonunda kür havuzundan çıkartılan numuneler sıcaklığı $23{ }^{\circ} \mathrm{C}$ 
Erken Yaş Yüksek Dayanımlı Çimento Băğlayıcılı Kompozitlerle Üretilen Onarım Sistemlerinin Eğilme Performansı ve Yansıma Çatlağı Davranışı

ve nemi $\% 50$ olan kür odasinda en az 1 yıl boyunca muhafaza edilmişlerdir. Daha sonra numuneler $30 \mathrm{~mm}$ kalınlığ uçlu testere yardımıyla kesilmişlerdir. Bu kesim yüzeyi aynı zamanda her tabakalı numune için alt tabakada aynı yüzey durumunu sağlamıştır. Hazırlanan ATB numunelerinin üzerlerine, HESECC ve OM karışımları $35 \mathrm{~mm}$ kalınlıkta dökülmüştür [13]. 24 saat sonra kalıplarından çıkartılan numuneler özel hava geçirimsiz poşetlerde $\% 95 \pm 5$ nemde ve $23 \pm 2{ }^{\circ} \mathrm{C}$ sicaklıkta deney gününe kadar kür edilmişlerdir. Hazırlanan tabakalı numunelerin eğilme performanslarını belirlemek için arazideki durum göz önüne alınarak kaplama yüzeyi altta (çekme yükünde) ATB yüzeyi ise üste (basınç yükünde) olacak şekilde dört noktalı eğilmede çekme testi 6 saat, 7 ve 28 günlük yaşlarda gerçekleştirilmiştir. Her yaş için dört adet numune test edilmiştir.

Yansıma çatlağının laboratuvar ortamında modellenmesi için daha önce literatürde gerçekleştirilen deney metodu kullanılmıştır [13-16]. Bu deney metodu hazırlanan kompozit kirişin dört noktalı eğilme yüküne maruz bırakılarak değerlendirilmesidir. Öncelikle

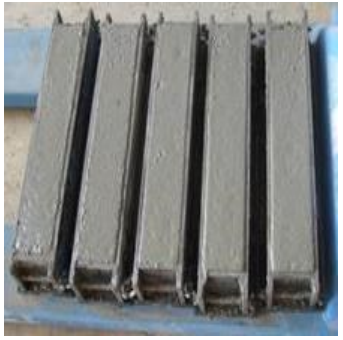

(a)

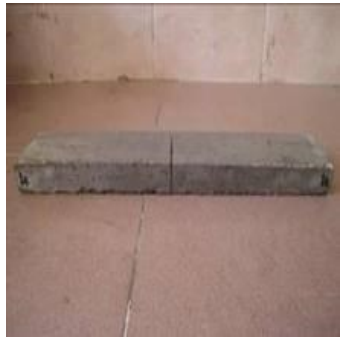

(b)

$400 \times 75 \times 80 \quad \mathrm{~mm}$ boyutlarındaki demir kiriş kalıplarına ATB karışımları dökülerek (Şekil 1-a) 24 saat sonra numuneler kalıptan çıkartılıp 27 gün boyunca kirece doygun suda bekletilmişlerdir. Bu sürenin sonunda kür havuzundan çıkartılan numuneler sıcaklığı $23{ }^{\circ} \mathrm{C}$ ve bağıl nemi \%50 olan kür odasinda en az 1 yıl boyunca muhafaza edilmişlerdir. Ardından numuneler elmas uçlu testere ile kesilerek $400 \times 75 \times 30 \mathrm{~mm}$ boyutlarında numuneler elde edilmiştir. Daha sonra bu numuneler tam ortalarından ikiye kesilerek alt tabakada daha önce meydana gelmiş olan bir çatlak oluşturulmuştur (Şekil 1-b). Bu şekilde hazırlanan ATB numuneleri $400 \times 75 \times 80 \mathrm{~mm}$ boyutlarındaki kalıplara elmas uçlu testere ile kesilen yüzeyleri üste gelecek şekilde yerleştirilerek (Şekil 1-c) üzerlerine $35 \mathrm{~mm}$ kalınlığında eğilmede çekme dayanımı testinde kullanılan HESECC ve OM karışımları dökülmüştür. 24 saat sonra kalıptan çıkartılan ve deney gününe kadar $\% 95 \pm 5$ bağll nemde ve $23 \pm 2{ }^{\circ} \mathrm{C}$ sicaklıktaki özel hava geçirimsiz poşetlerde kür edilen numunelerin 6 saat, 7 ve 28 günlük yaşlarda dört noktalı eğilmede çekme testi yapılarak yansıma çatlağı performansları test edilmiştir (Şekil 1-d).

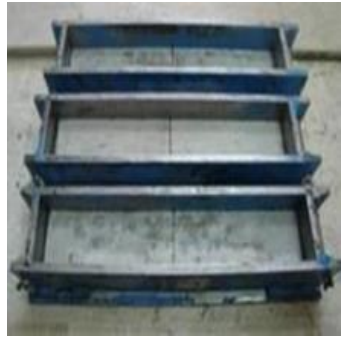

(c)

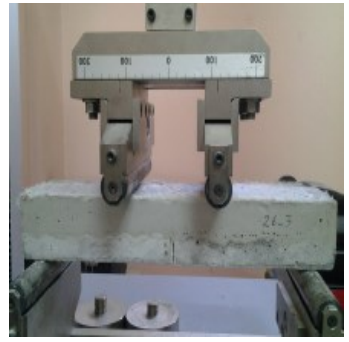

(d)

Şekil 1. Yansıma çatlağı deneyi için numunelerin hazırlanması ve test edilmesi

\section{BULGULAR VE TARTIŞMA}

\subsection{Monolitik Numuneler}

Monolitik numuneler üzerinde temel mekanik özellikleri 6 saat, 7 gün ve 28 günlük kür sürelerinin tamamlanmasının ardından belirlenmiştir. Numunelerden elde edilen sonuçların ortalaması Çizelge 4'te gösterilmektedir.
6 saatlik ortalama basınç dayanımı sonuçları değerlendirildiğinde HESECC karışımının $27 \mathrm{MPa}$ ile en yüksek sonucu verdiği görülmüştür. Benzer yaşta, HESECC-HA ve OM karışımları $22 \mathrm{MPa}$ ortalama basınç dayanımı sonucu vermiştir. Basınç dayanımı sonuçları karışım türünden bağımsız bir şekilde 28 günlük kür süresinin sonuna kadar artış sergilemiştir. Ancak bu durum, sonuçlarda 7. gün sonuna kadar gözlemlenen artışlarla kıyaslandığında 7-28 gün arasındaki artışlara 
kıyasla çok daha kısıtlı kalmış ve zaman içerisinde hidrate olmamış taneciklerin miktarının azalmasıyla ilişskilendirilmiştir. Literatürde her ne kadar suya doygun HA kullanımının içsel kürleme yoluyla hidratasyon reaksiyonlarının hızlanmasına katk1 sağlayacağı belirtilmiş olsa da basınç dayanımı sonuçları bakımından bu sonucu destekleyen bir bulgu bulunmamıştır. Çizelge 4'ten de görülebileceği üzere HESECC karışımının ortalama basınç dayanımı sonuçları öngörülen tüm kür süreleri için HA kullanımıyla düşüs göstermiştir. $\mathrm{Bu}$ durum HA'nın yer değiştirdiği kuvars kumuna kıyasla dayanımının çok daha az olmasıyla ilişkilendirilmiştir. Basınç dayanımı sonuçlarında her ne kadar değişimler gözlemlenmiş olsa da, farklı karışımlardan 6 saat sonrasında elde edilen en düşük değer (22 MPa ile OM ve HESECC-HA karışımlarından) hızlı onarım uygulamalarında kullanılmak üzere bir malzemeden beklenen ve literatürde belirtilen minimum basınç dayanımı sonuçlarından daha yüksek bulunmuştur $[17,18]$.

Çizelge 4. Monolitik numunelerin farklı mekanik özelliklerinin ortalama sonuçları

\begin{tabular}{|l|c|c|c|c|c|c|c|c|c|}
\hline \multirow{2}{*}{ Karışım Adı } & \multicolumn{3}{|c|}{ Basıç Dayanımı (MPa) } & \multicolumn{2}{c|}{ Eğilme Dayanımı (MPa) } & \multicolumn{4}{c|}{ Sehim (mm) } \\
\cline { 2 - 11 } & $6 \mathrm{~s}$. & $7 \mathrm{~g}$. & $28 \mathrm{~g}$. & $6 \mathrm{~s}$. & $7 \mathrm{~g}$. & $28 \mathrm{~g}$. & $6 \mathrm{~s}$. & $7 \mathrm{~g}$. & $28 \mathrm{~g}$. \\
\hline HESECC & 27 & 85 & 95 & 8,0 & 10,9 & 11,1 & 3,6 & 1,4 & 1,0 \\
\hline HESECC-HA & 22 & 74 & 83 & 7,9 & 10,1 & 11,3 & 3,7 & 2,6 & 2,4 \\
\hline OM & 22 & 69 & 76 & 5,1 & 7,7 & 8,1 & 0,57 & 0,38 & 0,31 \\
\hline
\end{tabular}

Karışımların ortalama eğilme dayanımı sonuçları 6 saat sonunda 5,1 ile 8,0 $\mathrm{MPa}$ arasında değişim göstermiştir. Çizelge 4'ten de görüldüğü üzere, 6 saat sonunda en yüksek eğilme dayanımı HESECC karışımından elde edilirken OM karışımı en düşük eğilme dayanımı sonucu vermiştir. Kuvars kumunun HESECC karışımında suya doygun HA ile yer değiştirilmesi basınç dayanımı sonuçlarındaki kadar belirgin olmasa da eğilme dayanımı sonuçlarının genellikle azalmasına yol açmıştır. Sonuçlardaki değişimlere rağmen çalışma kapsamında geliştirilen HESECC ve HESECC-HA karışımlarının tüm kür süreleri sonrasında kayıt altına alınan ortalama eğilme dayanımı değerleri OM karışımından ve farklı kaynaklarda çeşitli onarım malzemeleri için belirtilen minimum değerlerden oldukça yüksek bulunmuştur [17,18].

Karışımların süneklilikleriyle ilgili bilgi veren ortalama sehim sonuçları Çizelge 4'te gösterilmektedir. Çizelgeden de görüldüğü gibi, öngörülen tüm yaşlarda en düşük ortalama sehim değerleri OM numunelerinden elde edilmiştir. Diğer taraftan, farklı karıșımlar arasında tüm kür süreleri için en yüksek sehim sonuçları HESECC-HA karışımından elde edilmiştir. HESECC karışımlarıyla karşılaştırıldığında özellikle 7 ve 28 gün sonunda HESECC-HA karışımlarının sehim sonuçları arasındaki farkı açtığı gözlemlenmiştir. Bu gözleme dayalı olarak HA kullanımının HESECC karışımlarının sehim kapasitelerini önemli ölçüde arttırdığı belirtilebilir. HA'nın yer değiştirdiği kuvars kumuna kıyasla daha büyük tane boyut dağılımına sahip olması sebebiyle matriste lif dağılımını olumsuz etkileyerek karışımların sehim kapasitelerini azaltması beklenmiş olsa da bunun tersi bir davranış gözlemlenmiştir. Elde edilen bu sonuçlar HA kullanımının matris kırılma tokluğu değerlerini düşürmedeki etkinlikleriyle ilişkilendirilmiştir. Düşük matris kırılma tokluğu sonuçları bölgesel büyük çatlaklar yerine çoklu mikro çatlak oluşumu aracılığıyla daha yüksek süneklik (sehim) sonuçlarının elde edilmesinde önemli rol oynamıştır [12].

\subsection{Tabakalı Numuneler}

\subsubsection{Eğilme Performans}

Hazırlanan alt tabaka beton (ATB) numunelerinin üzerlerine HESECC, HESECC-HA ve OM karışımları $35 \mathrm{~mm}$ kalınlığında dökülüp her 
Erken Yaş Yüksek Dayanımlı Çimento Bağlayıcılı Kompozitlerle Üretilen Onarım Sistemlerinin Eğilme Performansı ve Yansıma Çatlağı Davranışı

karışımdan 4 adet numune dört noktalı eğilmede çekme testine maruz bırakılarak eğilme performansları test edilmiştir. Numunelere 6 saat, 7 gün ve 28 günlük yaşlarda uygulanan dört noktalı eğilmede çekme deneyi sonuçları Çizelge 5'te görülmektedir. Numunelerin test yaşlarına göre (6 saat, 7 ve 28 gün) eğilme dayanımı - sehim grafikleri de HESECC karışımı için Şekil 2'de, HESECC-HA karışımı için Şekil 3'te ve OM için Şekil 4'te verilmiştir.
Çizelge 5'te verilen eğilme dayanımı sonuçlarına bakıldığında farklı HESECC karışımları OM karışımına göre oldukça üstün bir performans sergilemişlerdir. HESECC, HESECC-HA ve OM karışımlarının 28 günlük eğilme dayanımları sirasiyla 12,23 MPa, 13,64 MPa ve 8,32 MPa'dır. 28 günlük HESECC karışımları birbirleriyle karşılaştıııldıklarında ise HESECC-HA karışımının HESECC karışımına göre yaklaşık olarak \%10 oranında daha yüksek eğilmede çekme dayanımına sahip olduğu görülmektedir.

Çizelge 5. Tabakalı numunelerin dört noktalı eğilmede çekme deneyi ortalama sonuçları

\begin{tabular}{|c|c|c|c|c|c|c|}
\hline \multirow{2}{*}{ Karışım Ad 1} & \multicolumn{3}{|c|}{ Eğilme Dayanımı (MPa) } & \multicolumn{3}{c|}{ Sehim (mm) } \\
\cline { 2 - 7 } & $6 \mathrm{~s}$. & $7 \mathrm{~g}$. & $28 \mathrm{~g}$. & $6 \mathrm{~s}$. & $7 \mathrm{~g}$. & $28 \mathrm{~g}$. \\
\hline HESECC & 4,60 & 11,59 & 12,23 & 3,28 & 2,22 & 2,05 \\
\hline HESECC-HA & 5,27 & 11,52 & 13,64 & 3,09 & 2,56 & 2,49 \\
\hline OM & 3,74 & 7,49 & 8,32 & 0,34 & 0,40 & 0,45 \\
\hline
\end{tabular}
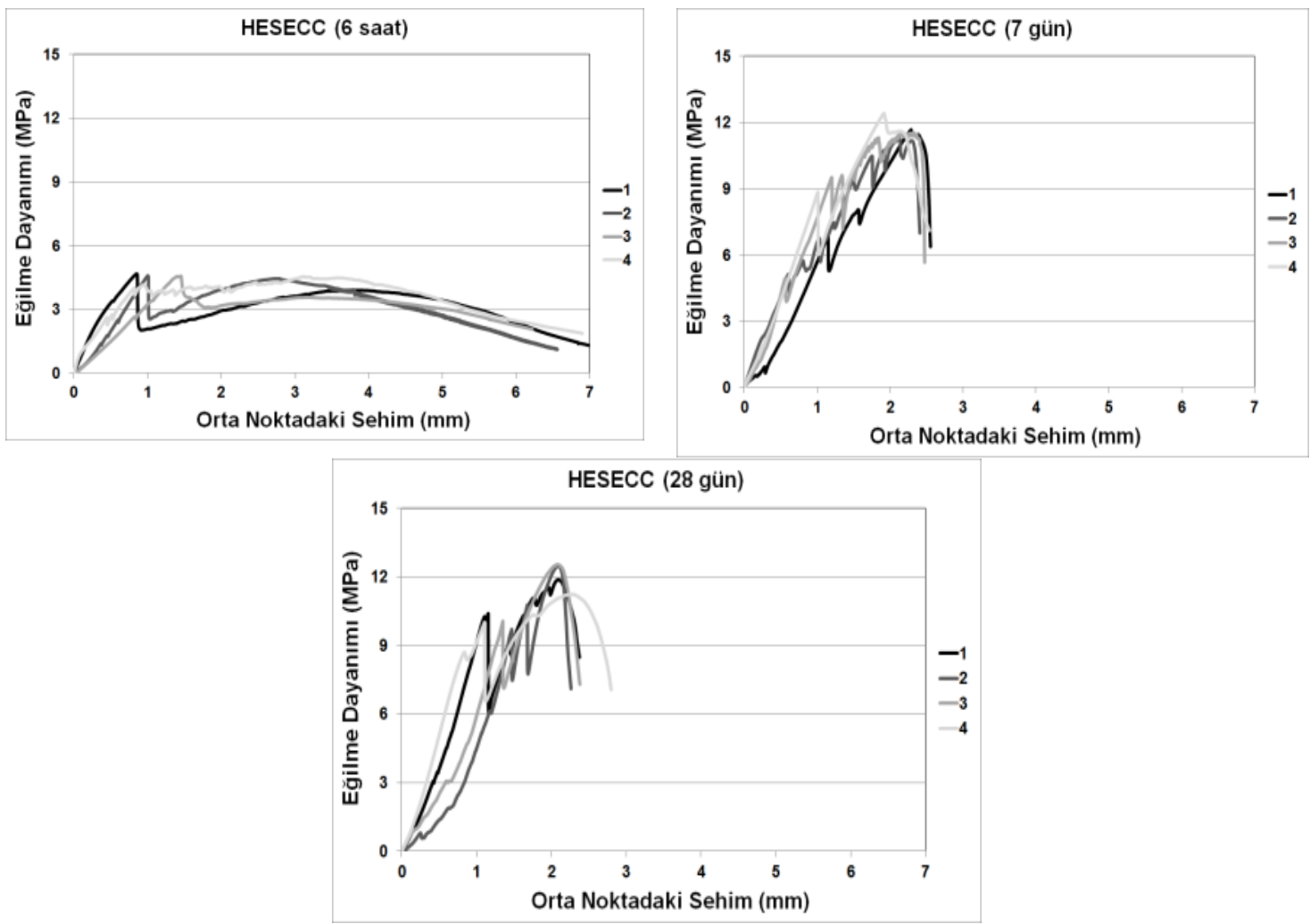

Şekil 2. HESECC karışımının eğilme dayanımı-sehim ilişkisi 

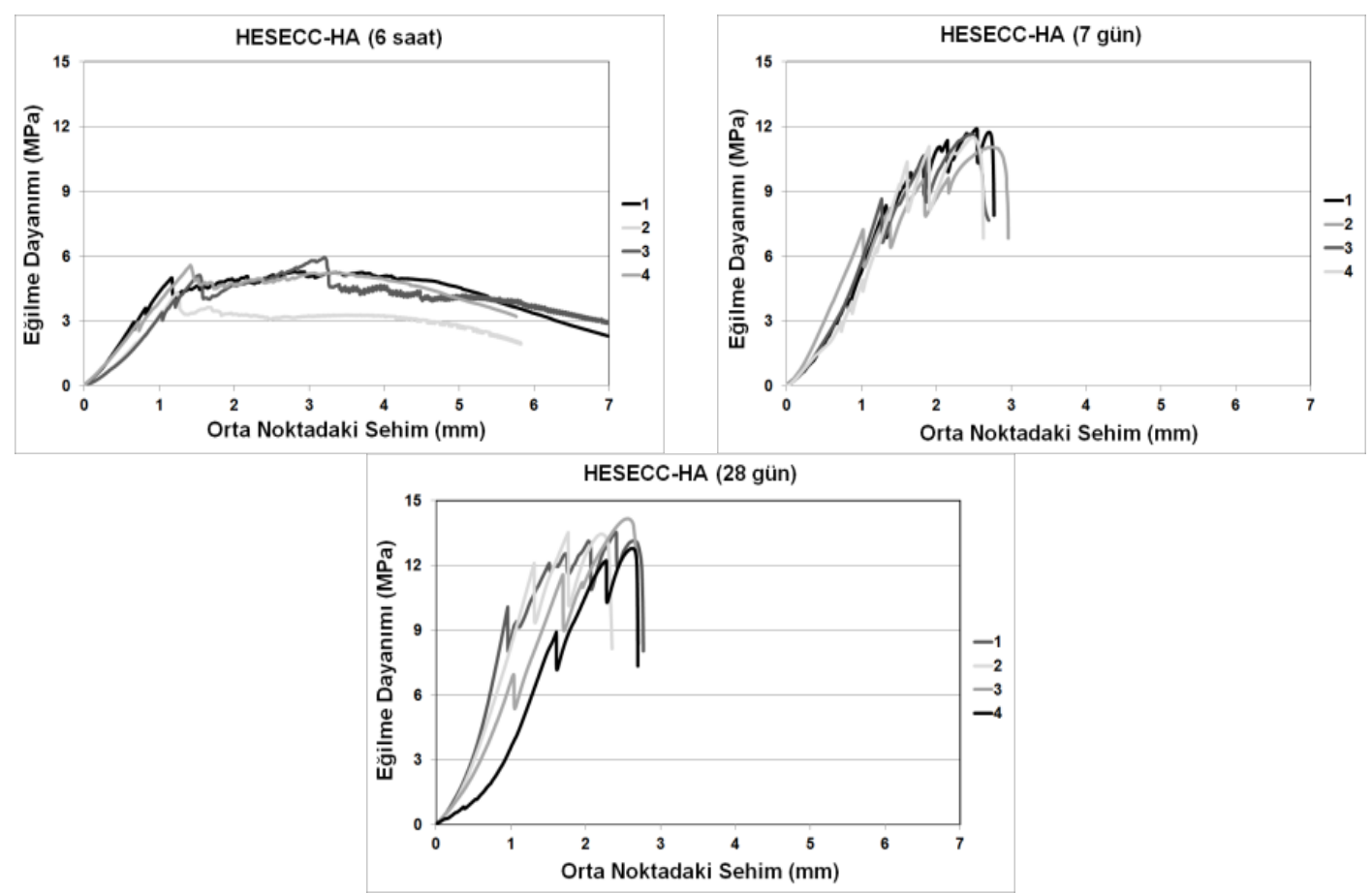

Şekil 3. HESECC-HA karışımının eğilme dayanımı-sehim ilişskisi
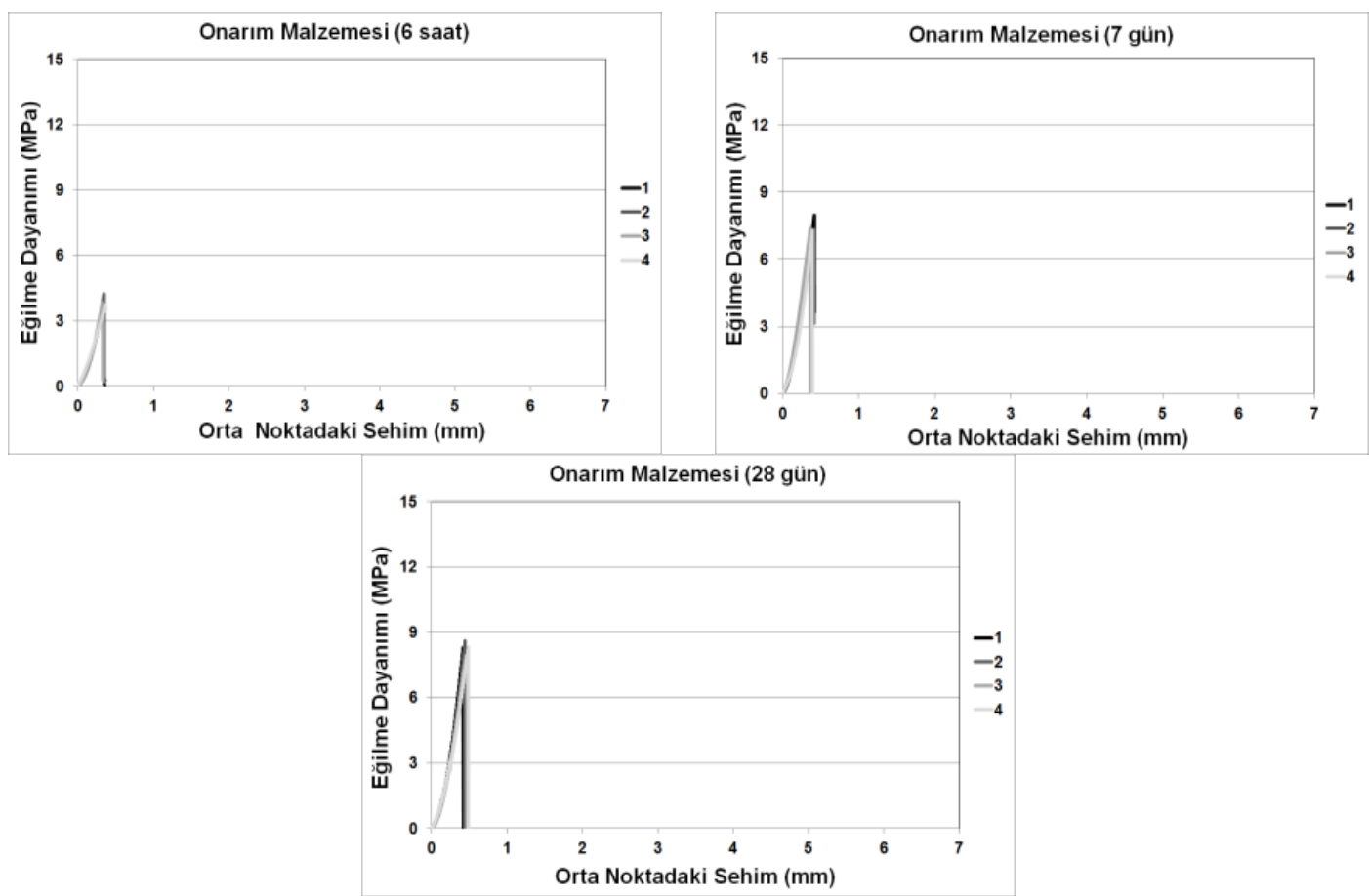

Şekil 4. OM karışımının eğilme dayanımı-sehim ilişskisi 
Erken Yaş Yüksek Dayanımlı Çimento Băğlayıcılı Kompozitlerle Üretilen Onarım Sistemlerinin Eğilme Performansı ve Yansıma Çatlağı Davranışı

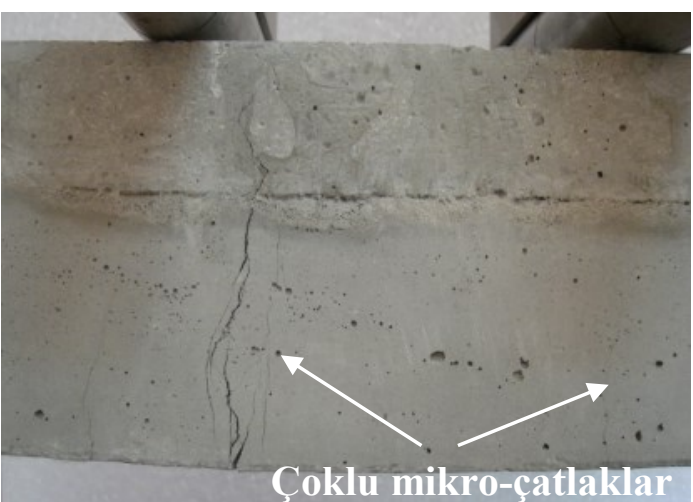

(a)

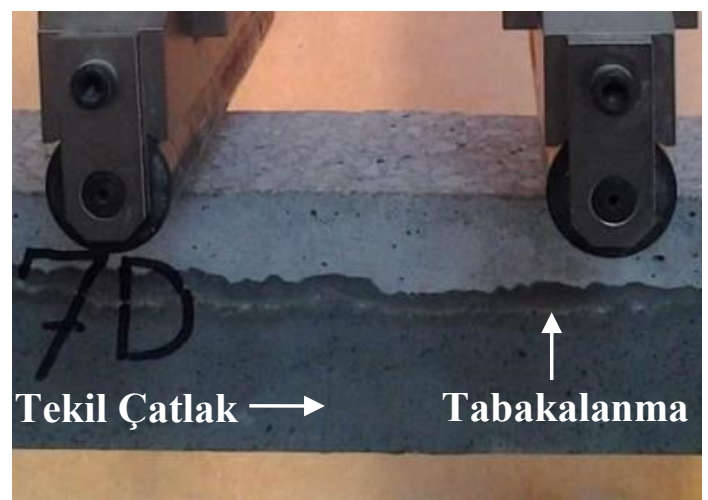

(b)

Şekil 5. Tabakalı HESECC (a) ve OM (b) karışımlarının tipik kırılma davranışları

Çizelge 5'te ve Şekil 2, 3 ve 4'te görüldüğü gibi genel olarak bütün karışımlarda deney yaşı ile sehim yani süneklilik ters orantılıdır. Tabakalı HESECC karışımları sahip oldukları sünek yapıları itibariyle OM karışımına göre oldukça yüksek sünekliliğe sahip olmuşlardır. HESECC karışımları eğilme sertleşmesi (flexural-hardening) davranışı altında çoklu çatlak oluşumu sergileyerek eğilme yükü altında kırılırken (Şekil 5-a) OM karışımı kırılgan bir davranış göstermiştir (Şekil 5-b). Dolayısıyla bütün deney yaşları için HESECC karışımları OM karışımına göre çok daha yüksek sehim değerine yani yüksek sünekliliğe sahip olmuştur. Genel olarak en yüksek sehim değerlerini ise HESECC-HA karışımı göstermiştir. HESECC karışımlarının yük altında göstermiş oldukları üstün performanslarının nedenleri önceki bölümlerde detaylandırılan malzeme temel mekanik özellikleriyle ilişkilendirilmiştir.

Şekil 5'te açıkça görüldüğü gibi HESECC ve OM karışımları farklı kopma davranışları sergilemişlerdir. HESECC karışımlarında numune üzerinde şekil değiştirme sertleşmesi özelliğinden ötürü çoklu mikro çatlaklar deney sonlanmıştır (Şekil 5-a). OM karışımında ise deney süresince önce tekil bir çatlak oluşarak alt tabaka betonu ve onarım malzemesi (OM) arasında küçük bir bölgede de olsa tabakalaşma yani bağ kopması oluşmuş olup (Şekil 5-b) numunenin gevrek bir şekilde kırılmasıyla deney tamamlanmıştır. Dolayısıyla malzemelerin tabakalı bir şekilde (geleneksel beton + onarım malzemesi) eğilme yükü altındaki davranışları bakımından da HESECC karışımları OM karışımına göre daha üstün olmuştur.

\subsubsection{Yansıma Çatlağı Davranışı}

Hazırlanan alt tabaka beton (ATB) numunelerinin üzerlerine HESECC, HESECC-HA ve Onarım Malzemesi (OM) karışımları $35 \mathrm{~mm}$ kalınlığında dökülerek her karışımdan 3 adet numune dört noktalı eğilmede çekme testine maruz bırakılıp yansıma çatlağı performansları test edilmiştir. Yansıma çatlağı testi için hazırlanan numuneler 6 saat, 7 ve 28 günlük yaşlarda test edilmiş olup ortalama sonuçlar Çizelge 6'da özetlenmektedir.

Çizelge 6. Tabakalı numunelerin yansıma çatlağı testi sonuçları

\begin{tabular}{|l|c|c|c|c|c|c|}
\hline \multirow{2}{*}{ Karışım Ad 1} & \multicolumn{3}{|c|}{ Eğilme Yükü (N) } & \multicolumn{3}{c|}{ Sehim (mm) } \\
\cline { 2 - 7 } & $6 \mathrm{~s}$. & $7 \mathrm{~g}$. & $28 \mathrm{~g}$. & $7 \mathrm{~g} \cdot$ & $6 \mathrm{~s}$. & $28 \mathrm{~g}$. \\
\hline HESECC & 1120 & 3459 & 3663 & 5.03 & 3.03 & 2.31 \\
\hline HESECC-HA & 760 & 3274 & 3575 & 4.69 & 4.26 & 3.07 \\
\hline OM & 685 & 1453 & 1825 & 0.27 & 0.34 & 0.31 \\
\hline
\end{tabular}



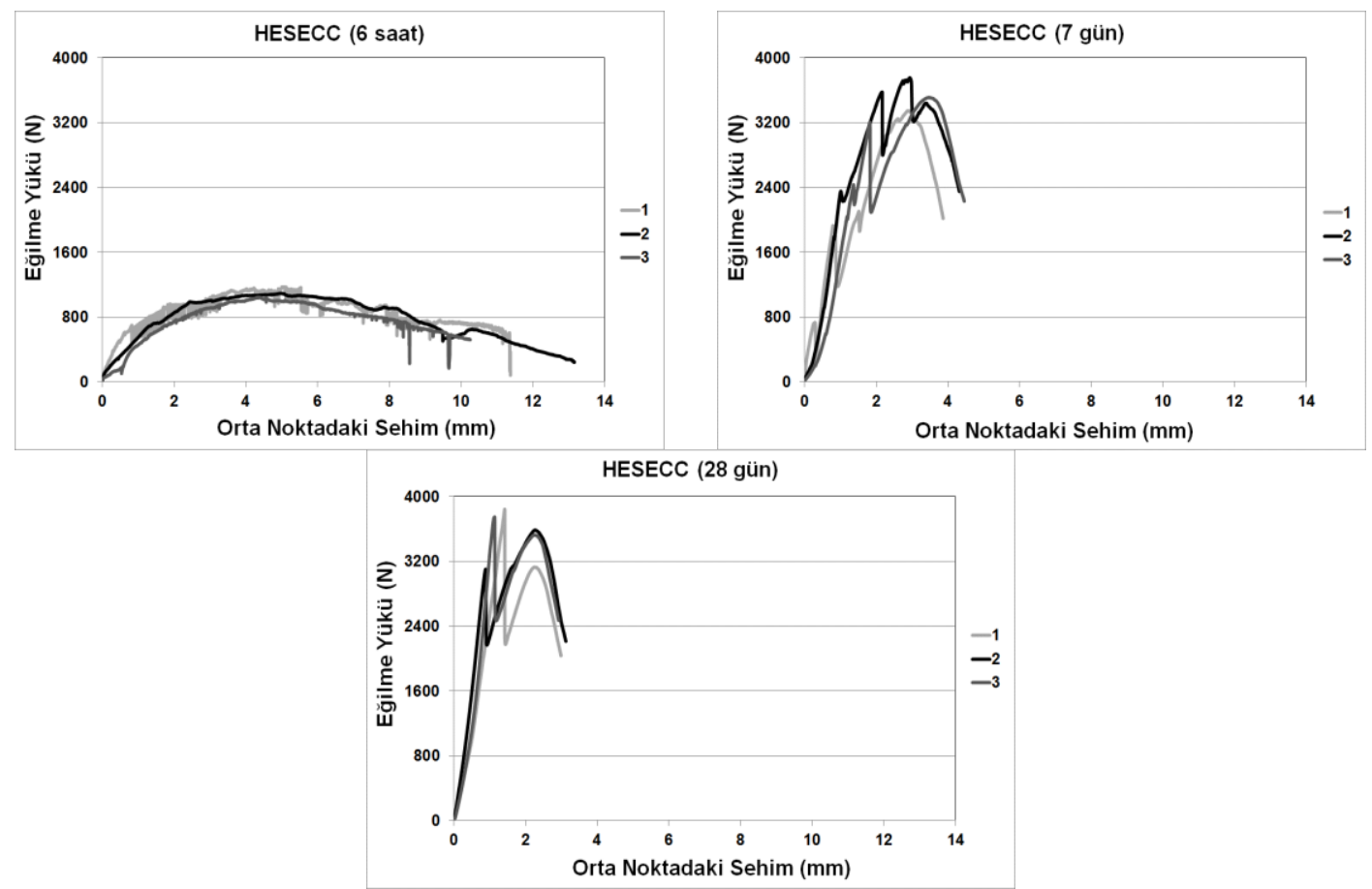

Şekil 6. HESECC karışımının eğilme yükü-sehim ilişsisi
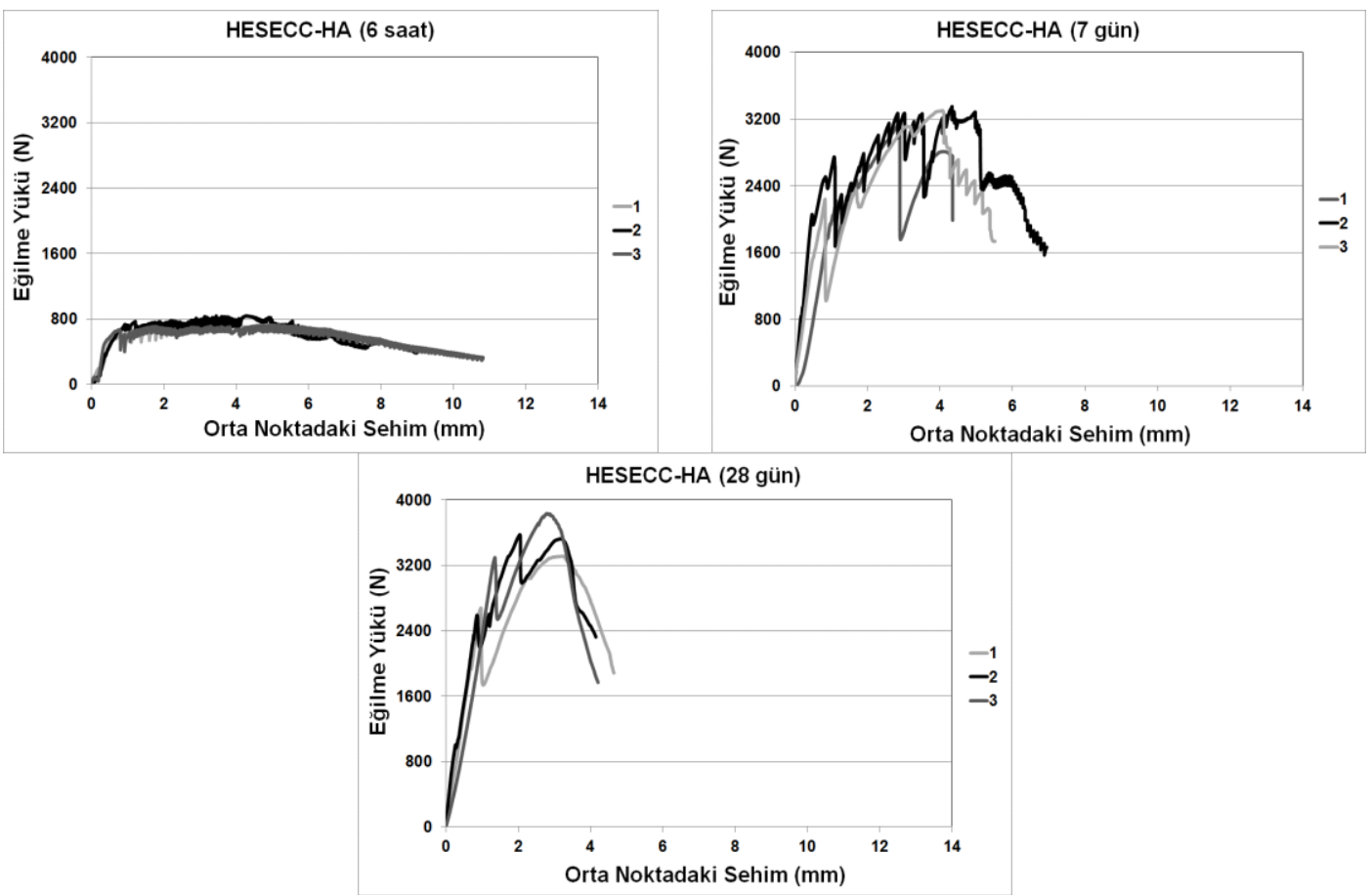

Şekil 7. HESECC-HA karışımının eğilme yükü-sehim ilişsisi 
Erken Yaş Yüksek Dayanımlı Çimento Bă̆layıcılı Kompozitlerle Üretilen Onarım Sistemlerinin Eğilme Performansı ve Yansıma Çatlağı Davranışı
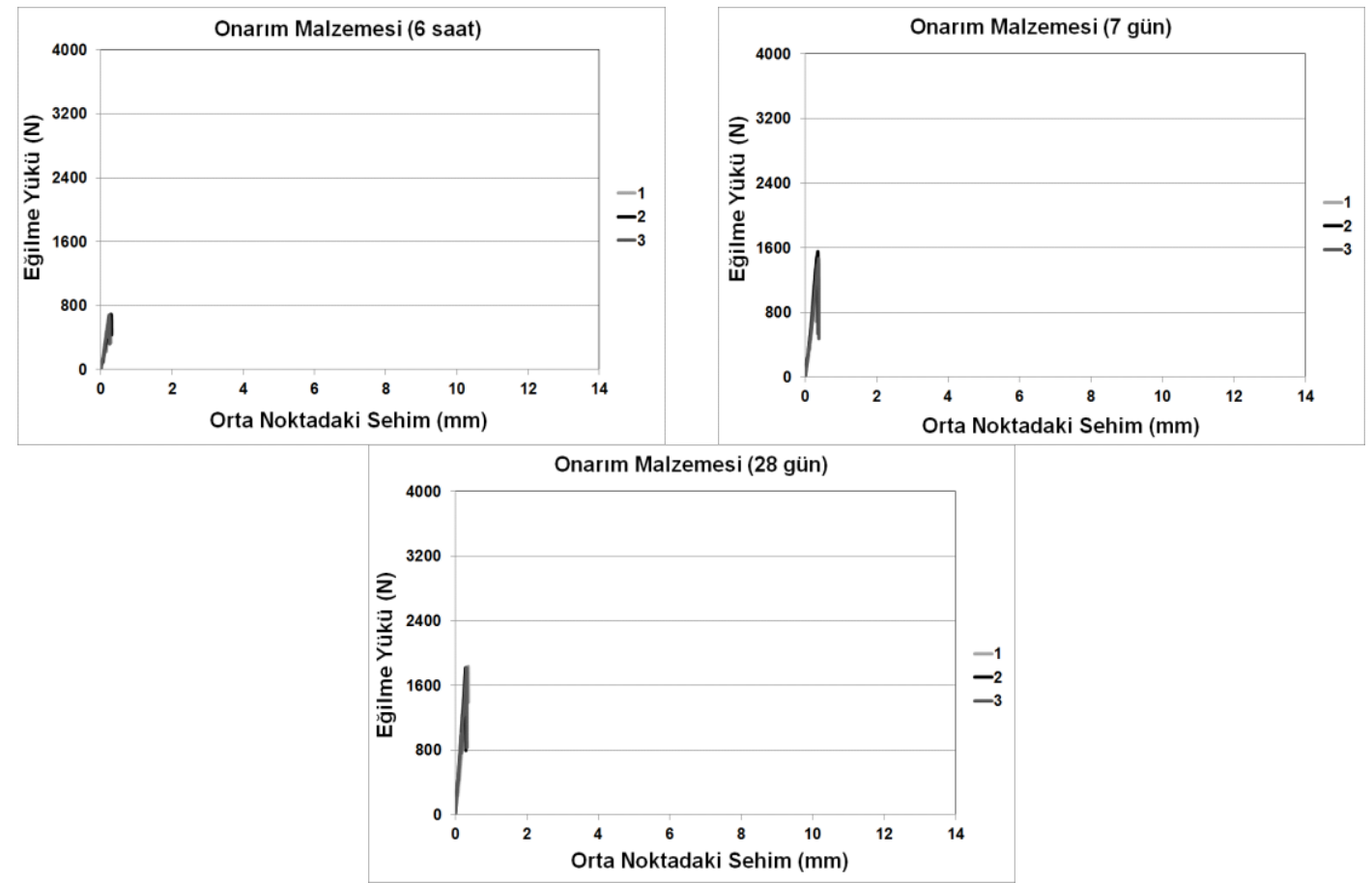

Şekil 8. OM karışımının eğilme yükü-sehim ilişkisi

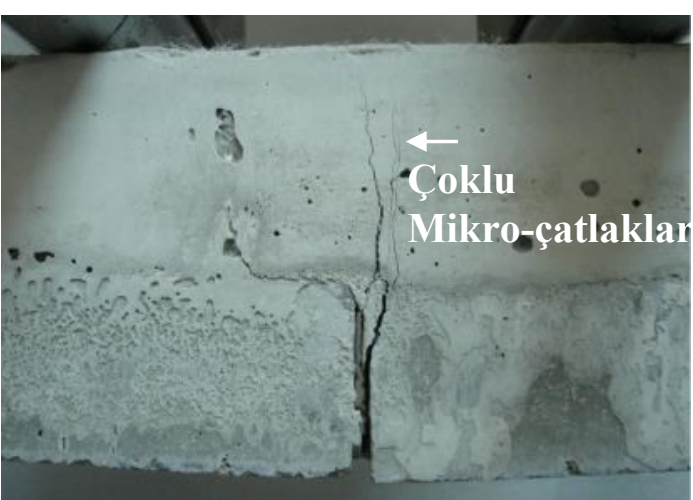

(a)

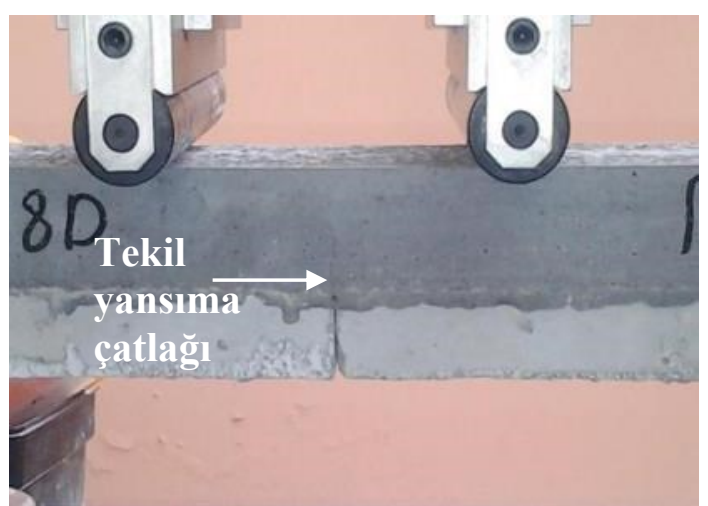

(b)

Şekil 9. Tabakalı HESECC (a) ve OM (b) karışımlarının yansıma çatlağı testi sonrası kırılma davranışları

Yansıma çatlağı testi sonuçlarına göre her test edilen yaşta OM karışımı en düşük eğilme yükü değerini alırken HESECC karışımı en yüksek eğilme yükü değerini almıştır. OM karışımının 28 günlük yaşta eğilme yükü değeri $1825 \mathrm{~N}$ olurken, HESECC ve HESECC-HA karışımlarının 7 günlük yaşta eğilme yükü değerleri sırasıyla $3459 \mathrm{~N}$ ve 3274 N olmuştur. Yani HESECC ve HESECC-HA karışımlarının 7 günde elde ettiği eğilme yükü değeri OM karışımının 28 günde yakaladığı eğilme yükü değerinin sırasıyla yaklaşık olarak \%89 ve \%79 fazlası olmuştur. Dolayısıyla eğilme yükü açısından karşılaştırıldığında HESECC karışımları OM karışımına göre çok üstün bir performans sergilemişlerdir.

Yansıma çatlağı testi sonrasında numunelerin test yaşlarına göre (6 saat, 7 gün ve 28 gün) elde edilen 
eğilme yükü - sehim grafikleri HESECC karışımı için Şekil 6, HESECC-HA karışımı için Şekil 7 ve OM karışımları için Şekil 8'de görülmektedir. Grafiklerden de anlaşılacağı üzere HESECC karışımlarının maksimum eğilme yükü seviyelerindeki sehim ile OM karışımının maksimum eğilme yükü seviyelerinde göstermiş olduğu sehim değeri arasında büyük bir uçurum gözlemlenmektedir. Bu uçurumun temel nedeni malzemelerin kırılma davranışlarının farklılığından kaynaklanmaktadır. HESECC karışımlarında kırılma Şekil 9-a'da görüldüğü gibi çok sayıda mikro çatlaklar oluşarak gerçekleşirken, OM karışımında tek bir çatlak oluşmuştur (Şekil 9-b) ve bu sebeple direk olarak kırılma bu çatlağın ilerlemesi ile gerçekleşmiştir. Dolayısıyla OM karışımında yansıma çatlağı üst tabakada tekil olarak kendini gösterirken, HESECC ve HESECC-HA karışımlarında çok sayıda mikro çatlaklar oluşarak yansıma çatlağı minimize edilmiştir. Özellikle onarımı gerçekleştirilen havaalanı ve otoyollarda en büyük sorunlardan biri olan yansıma çatlaklarının bu çalışma kapsamında geliştirilen HESECC karışımları ile minimize edileceği ve/veya ortadan kaldırılacağ düşünülmektedir.

\section{SONUÇLAR}

Çalışma kapsamında çekme yüklemeleri altında meydana gelecek çoklu mikro çatlak oluşturma özelliklerinden ödün vermeden erken yaş yüksek dayanımlı ve eski beton ile özellikle onarımın en zayıf olduğu erken yaşlarda en yüksek derecede boyutsal uyumluluk gösterecek yeni nesil yüksek performanslı çimento bağlayıcılı lif donatılı kompozit (ECC) karışımlarının geliştirilmesi amaçlanmıştır. Bu amaç doğrultusunda öncelikle erken yaş yüksek dayanımlı ECC (HESECC) deneme karışımları dökülerek temel mekanik özellikleri belirlenmiştir. İstenilen özellikleri sağlayan HESECC karışımları yeniden üretilip birinci bölümde temel mekanik özellikler tekrar belirlenmiştir. İkinci bölümde ise HESECC karışımlarının onarım malzemesi olarak kullanımında özelliklerinin belirlenmesi için tabakalı numunelerde eğilmede çekme dayanımı ve yansıma çatlağı testleri gerçekleştirilmiştir. $\mathrm{Bu}$ deneyler piyasada yaygın olarak kullanılan bir onarım malzemesi (OM) için de yapılarak HESECC karışımları ile karşılaştırılmıştır. Yapılan deneylerin sonuçları aşağıda maddeler halinde özetlenmiştir.

- Farklı HESECC karışımlarının temel mekanik özellikleri öngörülen tüm başlangıç süreleri için OM karışımından oldukça yüksek bulunmuştur. HESECC karışımlarının farklı dayanım sonuçları OM karışımına her ne kadar yakın bulunmuş olsa da sehim (süneklilik) sonuçları arasında önemli farklılıklar olduğu gözlemlenmiştir. Çalışma kapsamında üretilen HESECC karışımlarının tamamı literatürde bir onarım malzemesinden erken yaşta beklenen temel mekanik özelliklerin tamamını fazlasıyla karşılamıştır.

- Tabakalı numunelerin eğilme dayanımı değerlerine göre, HES-ECC karışımları OM karışımına göre oldukça üstün bir performans sergilemişlerdir. Ayrıca, HES-ECC karışımları sahip oldukları sünek yapıları itibariyle $\mathrm{OM}$ karışımına göre eğilme yükü altında oldukça yüksek sehim değerlerine yani sünekliliğe sahip olmuşlardır.

- Yansıma çatlağı testi sonuçları incelendiğinde, eğilme yükü açısından HESECC karışımları OM karışımına göre çok üstün değerlere sahip olmuşlardır. OM karışımında yansıma çatlağı üst tabakada tekil olarak kendini gösterirken, iki farklı HESECC karışımında çok sayıda mikro çatlaklar oluşarak yansıma çatlağı minimize edilmiştir.

\section{TEŞEKKÜR}

Bu çalışma Türkiye Bilimsel ve Teknolojik Araştırma Kurumu (TÜBİTAK) tarafindan MAG-112M035 numaralı proje kapsaminda desteklenmiştir.

\section{KAYNAKLAR}

1. Vaysburd, A., Brown, C., Bissonnette, B., Emmons, P., 2004. Realcrete vs. Labcrete. Concrete International, 26(2), 90-94. 
2. Engineers Canada, 2008. Adapting to Climate Change: Canada's First National Engineering Vulnerability Assessment of Public Infrastructure, 250.

3. Marlowe, I., 2003. Emission Factors Programme Task 4(b): Review of Cement Sector Pollution Inventory.

4. Yıldırım, G., Şahmaran, M., Balçıkanlı, M., Özbay, E., Lachemi, M., 2015. Influence of Cracking and Healing on the Gas Permeability of Cementitious Composites. Construction and Building Materials, 85, 217-226.

5. Yildırım, G., Alyousif, A., Şahmaran, M., Lachemi, M., 2015. Assessing the Self-Healing Capability of Cementitious Composites under Increasing Sustained Loading. Advances in Cement Research, 27(10), 581-592.

6. Wang, S., Li, VC., 2007. Engineered Cementitious Composites with High-Volume Fly Ash. ACI Materials Journal, 104(3), 233-241.

7. Şahmaran, M., Yıldırım, G., Erdem, T.K., 2013. Self-Healing Capability of Cementitious Composites Incorporating Different Supplementary Cementitious Materials. Cement and Concrete Composites, 35(1), 89-101.

8. Yildırım, G., Şahmaran, M., Ahmed, H.U., 2014. Influence of Hydrated Lime Addition on the Self-Healing Capability of High-Volume Fly Ash Incorporated Cementitious Composites. Journal of Materials in Civil Engineering, 27(6), 04014187.

9. Yıldırım, G., Keskin, Ö.K., Keskin, S.B., Şahmaran, M., Lachemi, M., 2015. A Review of Intrinsic Self-Healing Capability of Engineered Cementitious Composites: Recovery of Transport and Mechanical Properties. Construction and Building Materials, 101, 10-21.

10. Alyousif, A., Lachemi, M., Yıldırım, G., Şahmaran, M., 2015. Effect of Self-Healing on the Different Transport Properties of Cementitious Composites. Journal of Advanced Concrete Technology, 13(3), 112-123.

11. MDOT, 2009. Bridge Design Manual, Michigan Department of Transportation.
12. Sahmaran, M., Al-Emam, M., Ylldırım, G., Şimşek, Y.E., Erdem, T.K., Lachemi, M., 2015. High-Early-Strength Ductile Cementitious Composites with Characteristics of Low Early-Age Shrinkage for Repair of Infrastructures. Materials and Structures, 48(5), 1389-1403.

13. Yücel, H.E., Jashami, H., Şahmaran, M., Güler, M., Yaman, İ.Ö., 2013. Thin ECC Overlay Systems for Rehabilitation of Rigid Concrete Pavements. Magazine of Concrete Research, 65(2), 108-120.

14. Lim, Y.M., Li, V.C., 1997. Durable Repair of Aged Infrastructures using Trapping Mechanism of Engineered Cementitious Composites. Cement and Concrete Composites, 19(4), 171-185.

15. Kamada, T., Li, V.C., 2000. The Effect of Surface Preparation on the Fracture Behavior of ECC/Concrete Repair System. Cement and Concrete Composites, 22(6), 423-431.

16. Zhang, J., Li, V.C., 2002. Monotonic and Fatigue Performance in Bending of FiberReinforced Engineered Cementitious Composite in Overlay System. Cement and Concrete Research, 32(3), 415-423.

17. FHWA-RD-99-152, 1999. Manual of Practice: Materials and Procedures for Rapid Repair of Partial-Depth Spalls in Concrete Pavements. Federal Highway Administration, Washington, DC, 135.

18. Anderson, J., 2001. Paving Repair Finds a Four-Hour Champion. Concrete Construction, 46(12), 69-70. 